\title{
PATHOPHYSIOLOGY AND PHARMACOLOGY OF
}

HEART DISEASE 


\section{DEVELOPMENTS IN CARDIOVASCULAR MEDICINE}

51. Reiber, J.H.C., Serruys, P.W., Slager, C.J.: Quantitative coronary and left ventricular cineangiography. ISBN 0-89838-760-4.

52. Fagard, R.H., Bekaert, I.E., eds.: Sports cardiology. ISBN 0-89838-782-5.

53. Reiber, J.H.C., Serruys, P.W., eds.: State of the art in quantitative coronary arteriography. ISBN 0-89838-804-X.

54. Roelandt, J., ed.: Color doppler flow imaging. ISBN 0-89838-806-6.

55. van de Wall, E.E., ed.: Noninvasive imaging of cardiac metabolism. ISBN 0-89838-812-0.

56. Liebman, J., Plonsey, R., Rudy, Y., eds.: Pediatric and fundamental electrocardiography. ISBN 0-89838-815-5.

57. Higler, H., Hombach, V., eds.: Invasive cardiovascular therapy. ISBN 0-89838-818-X.

58. Serruys, P.W., Meester, G.T., eds.: Coronary angioplasty: a controlled model for ischemia. ISBN 0-89838-819-8.

59. Tooke, J.E., Smaje, L.H., eds.: Clinical investigation of the microcirculation. ISBN 0-89838-833-3.

60. van Dam, Th., van Oosterom, A., eds.: Electrocardiographic body surface mapping. ISBN 0-89838-834-1.

61. Spencer, M.P., ed.: Ultrasonic diagnosis of cerebrovascular disease. ISBN 0-89838-836-8.

62. Legato, M.J., ed.: The stressed heart. ISBN 0-89838-849-X.

63. Safar, M.E., ed.: Arterial and venous systems in essential hypertension. ISBN 0-89838-857-0.

64. Roelandt, J., ed.: Digital techniques in echocardiography. ISBN 0-89838-861-9.

65. Dhalla, N.S., Singal, P.K., Beamish, R.E., eds.: Pathophysiology of heart disease. ISBN 0-89838-864-3.

66. Dhalla, N.S., Pierce, G.N., Beamish, R.E., eds.: Heart function and metabolism. ISBN 0-89838-865-1.

67. Dhalla, N.S., Innes, I.R., Beamish, R.E., eds.: Myocardial ischemia. ISBN 0-89838-866-X.

68. Beamish, R.E., Panagia, V., Dhalla, N.S., eds.: Pharmacological aspects of heart disease. ISBN 0-89838-867-8.

69. Ter Keurs, H.E.D.J., Tyberg, J.V., eds.: Mechanics of the circulation. ISBN 0-89838-870-8.

70. Sideman, S., Beyar, R., eds.: Activation metabolism and perfusion of the heart. ISBN 0-89838-871-6.

71. Aliot, E., Lazzara, R., eds.: Ventricular tachycardias. ISBN 0-89838-881-3.

72. Schneeweiss, A., Schettler, G.: Cardiovascular drug therapy in the elderly. ISBN 0-89838-883-X.

73. Chapman, J.V., Sgalambro, A., eds.: Basic concepts in doppler echocardiography. ISBN 0-89838-888-0.

74. Chien, S., Dormandy, J., Ernst, E., Matrai, A., eds.: Clinical hemorheology. ISBN 0-89838-807-4.

75. Morganroth, J., Moore, E. Neil, eds.: Congestive heart failure. ISBN 0-89838-955-0.

77. Heintzen, P.H., Bursch, J.H., eds.: Progress in digital angiocardiography. ISBN 0-89838-965-8.

78. Scheinman, M., ed.: Catheter ablation of cardiac arrhythmias. ISBN 0-89838-967-4.

79. Spaan, J.A.E., Bruschke, A.V.G., Gittenberger, A.C., eds.: Coronary circulation. ISBN 0-89838-978-X.

80. Visser, C., Kan, G., Meltzer, R., eds.: Echocardiography in coronary artery disease. ISBN 0-89838-979-8.

81. Bayes de Luna, A., ed.: Therapeutics in cardiology. ISBN 0-89838-981-X.

82. Mirvis, D.M., ed.: Body surface electrocardiographic mapping. ISBN 0-89838-983-6.

86. Singal, P.K., ed.: Oxygen Radicals in the Pathophysiology of Heart Disease. ISBN 0-89838-375-7.

88. Morganroth, J., Moore, E.N., eds.: Silent myocardial ischemia. ISBN 0-89838-380-3.

93. Iwata, H., Lombardini, J.B., Segawa, T., eds.: Taurine and the heart. ISBN 0-89838-396-X. 


\section{PATHOPHYSIOLOGY AND PHARMACOLOGY OF HEART DISEASE}

Proceedings of the symposium held by the Indian section of the International Society for Heart Research, Chandigarh, India, February 1988

edited by

Inder S. Anand

Purshotam L. Wahi

Postgraduate Institute of Medical Education \&

Research, Chandigarh, India

Naranjan S. Dhalla

St. Boniface General Hospital Research Centre,

Winnipeg, Canada

Kluwer Academic Publishers

Boston/Dordrecht/London 
Distributors for North America:

Kluwer Academic Publishers

101 Philip Drive

Assinippi Park

Norwell, Massachusetts 02061 USA

Distributors for all other countries:

Kluwer Academic Publishers Group

Distribution Centre

Post Office Box 322

3300 AH Dordrecht, THE NETHERLANDS

\section{Library of Congress Cataloging-in-Publication Data}

Pathophysiology and pharmacology of heart disease : proceedings of a symposium held during the Annual Meeting of the Indian Section of the International Society for Heart Research, 25-28 February 1988, Chandigarh / edited by Inder S. Anand, Purshotam L. Wahi, Naranjan S. Dhalla. 102)

p. cm. - (Developments in cardiovascular medicine ; DICM

"This symposium was sponsored by the Council of Cardiac Metabolism of the International Society and Federation of Cardiology"-Half -title $\mathrm{p}$.

Includes index.

ISBN-13: 978-1-4612-8889-3

e-ISBN-13: 978-1-4613-1607-7

DOI: $10.1007 / 978-1-4613-1607-7$

1. Heart-Diseases-Pathophysiology-Congresses. 2. Heart-Diseases-Chemotherapy-Congresses. I. Anand, Inder S. II. Wahi, Purshotam L. III. Dhalla, Naranjan S. IV. International Society for Heart Research. Indian Section. Meeting (1988 : Chandigarh, India) V. Council on Cardiac Metabolism. VI. Series: Developments in cardiovascular medicine : v. 102.

[DNLM: 1. Heart Diseases-physiopathology-congresses. W1 DE997VME v. 102 / WG 200 P2926 1988]

RC681.A2P37 1989

$616.1^{\prime} 207-\mathrm{dc} 20$

DNLM/DLC

for Library of Congress

Copyright $\odot 1989$ by Kluwer Academic Publishers

Softcover reprint of the hardcover 1st edition 1989

All rights reserved. No part of this publication may be reproduced, stored in a retrieval system or transmitted in any form or by any means, mechanical, photocopying, recording, or otherwise, without the prior written permission of the publisher, Kluwer Academic Publishers, 101 Philip Drive, Assinippi Park, Norwell, Massachusetts 02061. 
To

Professor Santokh Singh Anand

founder-director of the

Postgraduate Institute of Medical Education \& Research

Chandigarh, India 


\section{Contents}

\section{Preface}

1 The newbom pig heart, a superior animal model of cardiac hypertrophy

Howard E. Morgan

Sigfried and Janet Weis Centre for Research, Geisinger Clinic, Danville, Pennsylvania, USA

2 Subcellular alterations in hypertrophied pig heart due to pressure overload

N.S. Dhalla, V. Panagia, C.E. Heyliger, V. Elimban, K.S. Dhalla and P.K. Singal

Division of Cardiovascular Sciences, St. Boniface General Hospital Research Centre, and Departments of Physiology, Anatomy and Medicine, University of Manitoba, Winnipeg, Canada

3 Cardiac sarcolemmal vesicles: ATP-dependent Ca ion transport and inhibition of protein kinase reactions by amrinone

Roland Vetter, Hannelore Haase and Liane Will-Shahab

Central Institute for Cardiovascular Research, Division of Cellular and Molecular Cardiology, Academy of Sciences of the GDR, Berlin, GDR

4 Transient changes in cyclic AMP and in protein kinase and phosphorylase activity during the cardiac cycle in the canine myocardium and the effect of propranolol

E.-G. Krause, Sabine Bartel, Inge Beyerdorfer, W. Freier, K. Gerber and D. Obst

Central Institute of Cardiovascular Research, and Centre of Engineering Scientific Instruments, Academy of Sciences of the GDR, Berlin, GDR

5 The role of creatine kinase and adenylate systems in the integration of oxidative phosphorylation and contractile function in the heart V.V. Kupriyanov, V.L Lakamkin, A.Ya. Steinschneider, N.A. Novikova, V.A. Saks and V.I. Kapelko Institute of Experimental Cardiology, USSR Research Centre for Cardiology, Moscow, USSR 
6 The action of calcium channel agonists on the mammalian ventricular myocardium

D. Bose, L.V. Hryshko, J.K. Saha, R.A. Bouchard and T. Chau Departments of Pharmacology \& Therapeutics, Anaesthesia and Internal Medicine, University of Manitoba, Winnipeg, Canada

7 Calcium and repertusion damage in heart muscle Philip A. Poole-Wilson

Department of Cardiac Medicine, National Heart and Lung Institute, London, UK

8 Cardioplegia and cellular calcium homeostasis

J.S. Juggi, A.M. Yousof, Hani J. Shuhaiber, A.G.H. Abdulla and K.S. Bhatia

Departments of Physiology, Cardiology and Physics, Kuwait University, Kuwait

9 Role of oxygen in myocardial ischaemia and reperfusion damage R. Ferrari, C. Ceconi, S. Curello, A. Cargnoni, F. De Giuli, G.M. Boffa and A. Albertini

Cattedra di Cardiologia and Cattedra di Chimica, Universita' di Brescia, Italy

10 Calcium channel blockers in experimental myocardial infarction

S.D. Seth and S.K. Maulik

Department of Pharmacology, All India Institute of Medical

Sciences, New Delhi, India

11 New trends in protection from life-threatening arrhythmias

L. Szekeres, M. Németh, J.Gy. Papp, Z. Szilvássy, É. Udvary and Á. Végh

Department of Pharmacology, Albert Szent-Györgyi University Medical School, Szeged, Hungary

12 The role of the blood pressure in the mechanism of congestive cardiac failure

P. Harris

Department of Cardiac Medicine, The Cardiothoracic Institute, London, UK 
13 Untreated congestive heart failure: studies of mechanisms I.S. Anand, R. Ferrari, G.S. Kalra, P.L. Wahi, P.A. Poole-Wilson and $P$. Harris

Postgraduate Institute of Medical Education \& Research, Chandigarh, India; Cattedra di Cardiologia, Universita' de Brescia, Italy; National Heart \& Lung Institute, London, UK

14 Hyponatraemia in congestive heart failure

C.T.G. Flear

University Department of Clinical Biochemistry and Metabolic

Medicine, University of Newcastle upon Tyne, UK

15 Dietary N-3 fatty acids and ischaemic heart disease

J.M.J. Lamers, L.M.A. Sassen, J.M. Hartog and P.D. Verdouw

Department of Biochemistry and Laboratory for Experimental

Cardiology, Erasmus University Rotterdam, The Netherlands

16 Atherosclerosis in a monkey model

R.N. Chakravarti

Department of Experimental Medicine, Postgraduate Institute of Medical Education \& Research, Chandigarh, India

17 Abnormalities of adrenergic mechanisms in diabetic cardiomyopathy P.K. Ganguly, R.E. Beamish, I.R. Innes and N.S. Dhalla Division of Cardiovascular Sciences, St. Boniface General Hospital Research Centre, and Departments of Anatomy, Physiology, Pharmacology and Medicine, University of Manitoba, Winnipeg, Canada

18 Circulatory response to high altitude

S.C. Manchanda

Department of Cardiology, All India Institute of Medical Sciences, New Delhi, India

19 Reversible effects of focused ultrasound on myocardium K.Yu. Bogdanov, S.I. Zakhrov and LV. Rosenshtraukh Institute of Experimental Cardiology, USSR Cardiology Research Centre, Moscow, USSR 


\section{Preface}

Research at the molecular and the cellular level has greatly enhanced our understanding of the pathogenesis and management of heart disease. Valuable contributions, towards this end, have been made by scientists from different disciplines including biochemistry, physiology, pathology, molecular biology and biophysics. We felt that it would be of interest and value to bring together experts from diverse specialities to present their work and to discuss the common problems encountered in their endeavours. In accordance, a symposium was organised in February 1988 at the Postgraduate Institute of Medical Education \& Research, Chandigarh. It was held during the annual meeting of the Indian section of the International Society for Heart Research. This book is a compilation of some of the papers presented at the symposium.

The symposium was sponsored by the Council on Cardiac Metabolism of the International Society and Federation of Cardiology. A number of Indian organisations gave generous financial help. These included the National Academy of Medical Sciences, Indian Council of Medical Research, Council of Scientific and Industrial Research and Department of Science and Technology.

Desktop publishing was used to prepare this volume. In doing so we came to appreciate the remarkable qualities, skills and help rendered by Professor Dharam Vir. For typing the manuscripts and for other secretarial assistance we gratefully acknowledge the help of Ravinder and Sawtantar. 
PATHOPHYSIOLOGY AND PHARMACOLOGY OF HEART DISEASE 